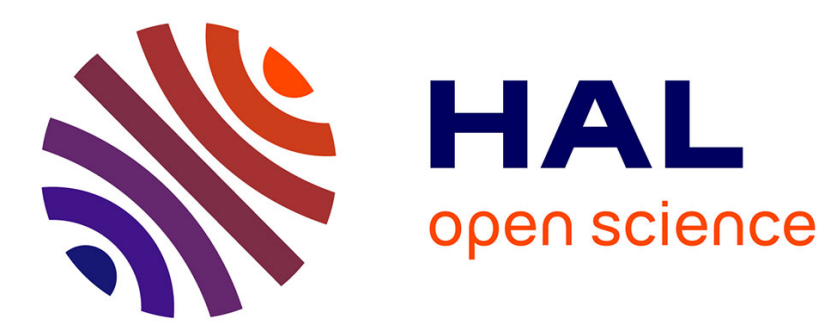

\title{
Grass strip effects on runoff and soil loss
}

Yves Le Bissonnais, Véronique Lecomte, Olivier Cerdan

\section{To cite this version:}

Yves Le Bissonnais, Véronique Lecomte, Olivier Cerdan. Grass strip effects on runoff and soil loss. Agronomie, 2004, 24 (3), pp.129-136. 10.1051/agro:2004010 . hal-00886045

\section{HAL Id: hal-00886045 \\ https://hal.science/hal-00886045}

Submitted on 1 Jan 2004

HAL is a multi-disciplinary open access archive for the deposit and dissemination of scientific research documents, whether they are published or not. The documents may come from teaching and research institutions in France or abroad, or from public or private research centers.
L'archive ouverte pluridisciplinaire HAL, est destinée au dépôt et à la diffusion de documents scientifiques de niveau recherche, publiés ou non, émanant des établissements d'enseignement et de recherche français ou étrangers, des laboratoires publics ou privés. 


\title{
Grass strip effects on runoff and soil loss
}

\author{
Yves Le BISSONNAIS ${ }^{\mathrm{a} *}$, Véronique LECOMTE ${ }^{\mathrm{a}, \mathrm{b}}$, Olivier CERDANa, \\ a INRA, Science du Sol, BP 20619, Ardon, 45166 Olivet Cedex, France \\ ${ }^{\mathrm{b}}$ Chambre d'Agriculture de Seine Maritime, BP 59, 76232 Bois Guillaume Cedex, France \\ ${ }^{c}$ BRGM ARN/MSO, 3 Av. Claude Guillemin, 45060 Orléans Cedex, France
}

(Received 1st January 2003; accepted 22 January 2004)

\begin{abstract}
The effects of grass strips on runoff interception, sediment trapping and soil loss were studied during two agricultural seasons. Field studies, conducted on loamy soil susceptible to sealing, allowed the comparison of three situations corresponding to buffer strip widths of 0,3 and $6 \mathrm{~m}$ located at the downslope end of a winter wheat field. In 1997-98 the 6-m grass strips led to an average increase in infiltration of 87\% with a coefficient of variation of $16 \%$ in comparison with a situation where no grass strip was present. The 3-m grass strip showed a slightly lower and more variable efficiency (average: $80 \%$, coefficient of variation: $19 \%$ in 97/98). Maximum grass strip infiltrability was estimated at about $50 \mathrm{~mm} / \mathrm{h}$. Grass strips reduced the event mean sediment concentration by a factor of four on average. Sediments deposited in the grass strip were enriched in sand and coarse silt, whereas exported sediments contained twice as much clay and fine silt as the soil surface horizon. Net soil loss from the field was decreased by $76 \%$ in $96 / 97$ and by $98 \%$ in $97 / 98$ for the 6-m grass strip.
\end{abstract}

runoff / soil loss / grass strip / infiltration capacity / sediment trapping

\section{INTRODUCTION}

Soil erosion is one of the major causes of soil degradation in the world and it also has severe off-site consequences [7]. In Western Europe, on-site short-term effects are not of primary concern, except if large gullies are formed [1]. However, the environmental consequences of runoff and sediment transport to streams and downslope ecosystems are increasingly alerting local authorities. Besides research on conservation tillage and cropping systems, there is a need for information on soil loss control systems such as grass strips and channels, which could control and reduce the downslope impact of overland flow and erosion [12, 26, 29]. Grass strips (GS) consist of bands of either planted or indigenous vegetation situated downslope of cropland or animal production facilities in order to reduce the export of nutrients, sediment and other pollutants from agricultural areas [9]. The infiltration capacity of grassland and pasture is generally much higher than that of arable land [23], and numerous experiments have shown the efficiency of grass strips for runoff re-infiltration [2, 3, 9, 17-25, 28, 30]. Only when grass strips are very narrow $(0.5$ to $1 \mathrm{~m})$ is their efficiency very limited [16, 20]. Runoff infiltration efficiency generally ranges between $30 \%$ and $70 \%$ with an annual variability lower than the event variability. Efficiency generally increases with increasing grass area and decreases with increasing slope gradient, initial moisture content and runoff volume [27]. The infiltration capacity of pasture may in some cases be reduced by compaction, water logging, or in the case of concentrated runoff and subsequent channelling [8,9]. The efficiency of grass strips also depends on the grass species, age, density, height, and on their management [8, 10, 13, 29]. Several studies also showed the ability of grass strips to trap sediments, even for a situation where they have no or little effect on runoff reduction [20]. Grass strips generally reduce sediment export by $30 \%$ to $100 \%$, and most of the time by more than $90 \%$.

Most of the studies on grass strips were carried out in the USA: only a few studies have been done in Europe, where runoff and erosion conditions may differ from those observed in the USA [23, 29]. Studies that were carried out in the UK on sandy loam, with artificial and natural vegetation, using small laboratory flumes with runoff and rainfall simulation, pointed out the effect of grass species and root density, as well as slope $[10,13]$. Field experiments by Van Dijk et al. [29] showed the effectiveness of pasture and young grass in reducing sediment discharge from upstream runoff on loamy soils. However, these experiments involved only runoff from a water reservoir which was applied to very narrow plots. Thus, the interaction between the cultivated field and the grass strip and the rainfall impact effect was not taken into account in these studies. There is therefore a need for experiments under natural rainfall and runoff conditions in the field, allowing a better understanding of the efficiency of grass strips and of its variability, which was shown to be very significant [19].

The aim of this work was to study the effect of 3-m and 6-mwide grass strips located downslope of winter wheat fields on silty loamy soils that are sensitive to crusting and erosion [14]. The experiments were carried out in the field under natural rainfall conditions during two agricultural seasons. This allowed

* Corresponding author: Yves.Le-Bissonnais@orleans.inra.fr 
the study of the temporal variability of grass strip efficiency under various conditions of rainfall amounts and intensity, vegetation development and the soil surface state.

\section{MATERIALS AND METHODS}

\subsection{Soil characteristics}

The experimental plots are located in the Pays de Caux (Normandie, France). The soil is a silt loam soil (Typic Hapludalf) developed on loess formations overlying a chalky limestone plateau. The soil characteristics are representative of the European loess belt conditions. The topsoil has a high silt content (more than 60\%), a low clay content (10 to 15\%) and a low organic matter content (less than 1.5\%). Due to their weak aggregate stability, the soils of Pays de Caux are particularly prone to surface sealing [11]. Under raindrop impact, aggregate breakdown and dispersion decrease both the infiltration capacity and detention storage, and runoff may occur even for low intensity rainfall [14].

\subsection{Experimental procedures}

Experimental studies were conducted in the field under natural rainfall, on eight plots during the agricultural season 1996/ 1997 and on eleven plots in 1997/1998. Ray-grass strips of $3 \mathrm{~m}$ and $6 \mathrm{~m}$ width, corresponding to standard sowing equipment width, were sowed downslope of a 54-m-long winter wheat field. The grass sowing direction was perpendicular to both the main slope and the wheat sowing direction. Two types of plots were installed: (i) two large 8-m-wide by $60-\mathrm{m}$-long plots (one with a 6-m-wide grass strip and one control plot without a grass strip) and (ii) nine small 2-m-wide by 60-m-long plots (three for each treatment: control, 3-m and 6-m-wide grass strips). The large plots were equipped with continuous runoff measurement devices (3.2 1 tipping buckets, corresponding to a resolution of $0.007 \mathrm{~mm}$ of runoff for the plot) and a sediment sampler (which sampled runoff and sediment at fixed time intervals). The high temporal resolution for runoff and soil loss measurements (less than $10 \mathrm{~s}$ resolution for $30 \mathrm{~mm} / \mathrm{h}$ of runoff) allowed the study of the temporal variability of grass strip efficiency during rainfall events, but without replicates. The small plots were equipped with collector tanks so that total runoff and sediment measurements could be made on the rainfall event timescale (collector tanks). These small plots allowed replications and control of the measurements from the large plots with a reduced temporal resolution, but at the same time without being dependent on electronic devices (Fig. 1). All plots were located between wheel tracks, allowing the farmer to operate regular farming operations in the field. The slope gradient of the plots ranged from 3 to $5.8 \%$ (Tab. I). Figure 1 shows the set of experimental plots during the $97 / 98$ season.

The grass was sown only a few months before the start of the measurements so that, at the start of the measurements, the vegetation density was relatively low and the root system was not completely developed.

During a rainfall event runoff and sediment samples were collected at regular time intervals on the large plots, while an

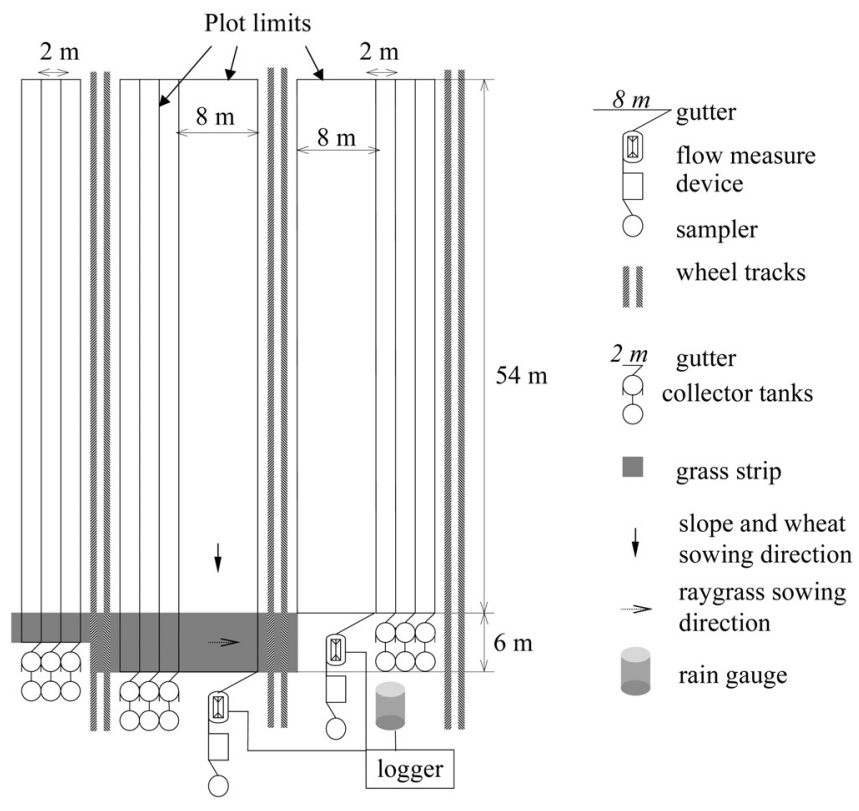

Figure 1. Schematic diagram of experimental field plots (97/98). All plots were bounded.

average sample for a given event was taken on the 2-m-wide plots. Sometimes a single value for two or more successive events occurring on the same day was obtained, so that the amount of data for the small plots was less than the total number of events. A grain size analysis was performed on samples collected during the first event that produced runoff downstream of the grass strips after a pesticide treatment performed on the 27 of February 98. The apparent fragment size distribution was measured by sieving the samples gently at $50 \mu \mathrm{m}$ and four fractions $<50 \mu \mathrm{m}$ were determined using a sedimentation column $(0-2,2-10,10-20$ and $20-50 \mu \mathrm{m})$. Elementary particle size distribution was determined after dispersion with $\mathrm{Na}$ resin and $24 \mathrm{~h}$ of stirring.

Soil surface conditions (crusting stage development, roughness and vegetation cover) were monitored after each rainfall event during the two seasons, using the method and typology described by Auzet et al. and Le Bissonnais et al. [1, 15]. It distinguishes between four crusting stages: F0: initial fragmentary structure, all particles are clearly distinguishable, F11: altered fragmentary state with structural crusts, F12: transitional: local appearance of depositional crusts, and F2: continuous state with depositional crusts.

\section{RESULTS AND DISCUSSION}

\subsection{Rainfall characteristics for the study period}

Rainfall was measured using automatic rain gauges with a $0.2 \mathrm{~mm}$ rain height resolution and $1 \mathrm{~s}$ time resolution for the recording of the bucket-tipping time. The two observation seasons (October 96 to September 97 and October 97 to September $98)$ had lower cumulative annual rainfall amounts $(653 \mathrm{~mm}$ and 
Table I. Plot characteristics.

\begin{tabular}{|c|c|c|c|c|c|c|c|c|c|c|}
\hline & $\mathrm{P} 1-\mathrm{P} 2$ & P3 & $\mathrm{P} 4$ & P5-P6 & P7-P8 & P9-P11 & P12-P14 & P15 & P16 & P17-P19 \\
\hline Season & & & $96 / 97$ & & & & $97 / 98$ & & & \\
\hline $\begin{array}{l}\text { Width } \\
(\mathrm{m})\end{array}$ & 2 & 8 & 8 & 2 & 2 & 2 & 2 & 8 & 8 & 2 \\
\hline $\begin{array}{l}\text { Wheat field length } \\
\text { (m) }\end{array}$ & 54 & 54 & 54 & 54 & 54 & 54 & 54 & 54 & 54 & 54 \\
\hline $\begin{array}{l}\text { GS length } \\
\text { (m) }\end{array}$ & 0 & 0 & 6 & 6 & 3 & 3 & 6 & 6 & 0 & 0 \\
\hline Runoff monitoring* & $\mathrm{C}$ & $\mathrm{F}$ & $\mathrm{F}$ & $\mathrm{C}$ & $\mathrm{C}$ & $\mathrm{C}$ & $\mathrm{C}$ & $\mathrm{F}$ & $\mathrm{F}$ & $\mathrm{C}$ \\
\hline $\begin{array}{l}\text { Slope } \\
(\%)\end{array}$ & $3-4$ & $3-5$ & $3-5.2$ & $3-5.5$ & $3.5-5.8$ & $3.2-4$ & $3.2-4$ & $3.2-4$ & $3.2-4$ & $3.2-4$ \\
\hline Filter strip vegetation & & & & Raj & & & & & & \\
\hline
\end{tabular}

*C: cumulative runoff measured by collector tanks; F: continuous flow measurements.

$727 \mathrm{~mm}$, respectively) than the mean over the last 25 years for the area $(831 \mathrm{~mm})$. Monthly rainfall amounts were highly variable, with very dry (3 to $10 \mathrm{~mm}$ in January, March and September 97 and in February and May 98) and very wet months (90 to $150 \mathrm{~mm}$ in November 96, May, June and December 97 and in April and September 98). During the study period data covering more than 100 rainfall events were collected. In total, 36 events exceeding $5 \mathrm{~mm}$ of rain were recorded. These rainfall events were characterised by a low mean rainfall intensity $(66 \%$ of the rainfall events had a mean intensity $<5 \mathrm{~mm} / \mathrm{h}$ and only $20 \%$ a mean intensity $>10 \mathrm{~mm} / \mathrm{h}$ ). However, rainfall events often included short periods (a few minutes) with high intensity rainfall $(>20 \mathrm{~mm} / \mathrm{h})$. The 10 days Antecedent Rainfall Index (ARI) was calculated for each of these events (Eq. (1)).

$$
A R I=\sum_{i=1}^{10} \frac{P_{d i}}{i}
$$

with $P_{d i}$ : rain of day $\mathrm{i}$ before the event.

Ca. $1 / 3$ of the events had an ARI $>12 \mathrm{~mm}$, and ca. $1 / 3$ of the events had an ARI $<6 \mathrm{~mm}$.

\subsection{Runoff from control plots (no grass strip)}

Runoff was measured for each rainfall event occurring between November and June of each season. Runoff data for 42 and 45 events on the control plots (no grass strip) are available for the two seasons, respectively. Runoff represented 29.1 and $56.6 \mathrm{~mm}$, respectively, corresponding to mean runoff coefficients (the ratio of runoff volumes to rainfall volumes for the corresponding rainfall events) of $10 \%$ and $19 \%$. The difference in runoff amount between the two seasons is due to higher rainfall amounts and intensities in 97/98, leading to more widely developed crusts on the field. The highest event runoff coefficients were ca. $80 \%$ and were observed during December 97 and January 98 rainfall events. During a heavy rainfall in June 97 the runoff coefficient was only ca. $40 \%$, due to a fully developed vegetation cover of winter wheat. Measurements of runoff volumes on the 8-m and 2-m-wide plots were in good agreement:

$$
\mathrm{R}_{\mathrm{C}-2 \mathrm{~m}}=1.01 \times \mathrm{R}_{\mathrm{F}-8 \mathrm{~m}}\left(\mathrm{n}=37 ; \mathrm{R}^{2}=0.98\right)
$$

with $\mathrm{R}_{\mathrm{C}-2 \mathrm{~m}}$ : runoff volume measured in collector tanks on 2-mwide plots; $\mathrm{R}_{\mathrm{F}-8 \mathrm{~m}}$ : runoff volume on 8 -m-wide plots as calculated from the tipping bucket measurements; n: number of observations with measurements available for both types of plots.

Four groups of runoff events may be distinguished for the analysis of rainfall-runoff relationships, by taking into account the soil surface conditions (crusting stage development) and vegetation cover [15]:

(1) Soil surface condition F11 (structural crust);

(2) Soil surface condition F12 (intermediate structural/sedimentary crust);

(3) Soil surface condition F2 (sedimentary crust) with vegetation cover $<40 \%$;

(4) Soil surface condition F2 with vegetation cover $>40 \%$.

Mean runoff coefficients increase with increasing crust development (from less than 1\% for group 1 to more than $30 \%$ for group 3 ) and then decrease to about $10 \%$ with vegetation cover development (group 4). These observations confirm the strong effect of soil surface conditions on runoff generation on cultivated fields on loamy soils as reported in earlier studies [1, $12,14]$.

\subsection{Effect of 6-m grass strips on runoff on the seasonal scale}

Runoff was significantly reduced downstream of the 6-m grass strip: only 28 and 27 runoff events were recorded downstream of the 6-m grass strip for the two observation seasons, respectively, compared with 42 and 45 runoff records upstream of the 6-m grass strip. The total runoff amount was reduced by $63 \%$ (to $10.7 \mathrm{~mm}$ ) and $84 \%$ (to $9.2 \mathrm{~mm}$ ) by the 6-m-wide grass strip for the two observation seasons, corresponding to a runoff coefficient (calculated for the rainfall events during the period of measurement) of $3.7 \%$ and $3 \%$, respectively. The slow development of the grass strip during the first season, due to late sowing in autumn, explains its somewhat lower efficiency. Overall, runoff was reduced by $77 \%$ over the two seasons. However, a high inter-event efficiency variability in grass strip efficiency, ranging from $7 \%$ to $100 \%$ (coefficient of variation), was observed, 


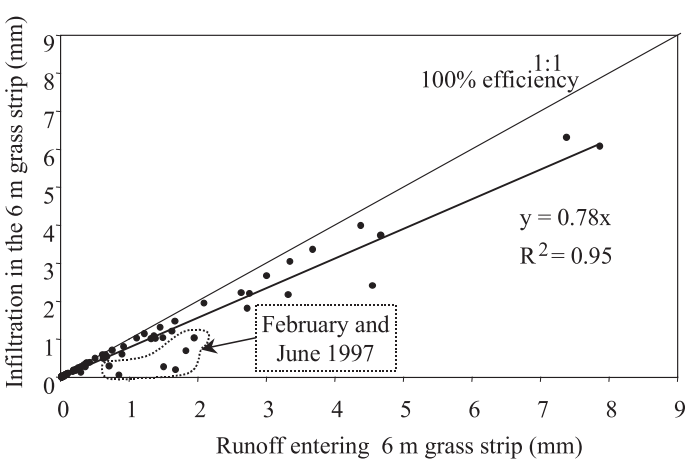

Figure 2. Infiltration into the 6-m grass strip as a function of runoff entering the grass strip. The 1:1 line corresponds to an efficiency of $100 \%$ of the grass strip. The slope of the linear regression gives the mean 6-m grass strip efficiency for runoff reduction.

which can be related to rainfall characteristics, soil moisture and surface conditions.

When the runoff coefficient downstream of the grass strip is calculated for the various rainfall events, the four groups of events defined previously for the control plot can no longer be distinguished. This indicates a significant variability in grass strip efficiency, which masks the differences that exist in the relationship between total runoff and total rainfall for different runoff event types. This variability becomes less marked when the winter wheat is well established on the field. Overall, the efficiency of the grass strip decreased with increasing rainfall amount and $100 \%$ efficiency was never observed when rainfall events exceeded $12 \mathrm{~mm}$. Two periods showed a low efficiency: February 97 and June 97. In February 97 the grass was not well developed due to late sowing. In June 97, the low efficiency was related to the high intensity of the rainfall. Infiltration in the grass strip is generally well related to the runoff amount entering the grass strip (Fig. 2). A statistical model using linear regression allows the prediction of runoff $\left(\mathrm{V}_{\mathrm{r}}\right)$ using rainfall amount $\left(\mathrm{P}_{\mathrm{c}}\right)$ and the Antecedent Rainfall Index (ARI) as input parameters (Eq. (3)):

$$
\mathrm{V}_{\mathrm{r}}=-161.9+34 \mathrm{P}_{\mathrm{c}}+13.7 \text { ARI. }
$$

This model explains $50 \%$ of runoff variability from the grass strip plot (downstream of the grass strip). A linear regression including antecedent rainfall gives a better description of runoff leaving than of runoff entering the grass strip (estimated as the runoff amount measured on the control plot), whereas a model based on rainfall amount only gives a better description of runoff entering than of runoff leaving the grass strip. This illustrates the influence of initial moisture conditions on grass strip efficiency $[3,27]$.

\subsection{Temporal variability of 6-m grass strip efficiency and infiltration capacity: examples from two events}

The 6-m grass strip efficiency was at its lowest for the event of June 8, 1997. Rainfall amount was moderate for this event $(6.4 \mathrm{~mm})$, but rainfall intensity was high with a mean intensity

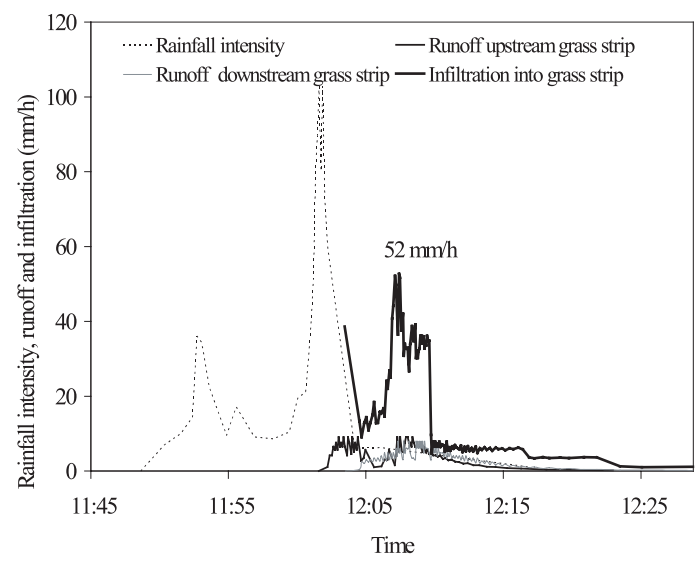

Figure 3. Rainfall intensity, runoff entering and leaving the 6-m grass strip and calculated grass strip infiltration capacity for the event of June 8, 1997.

of $5.3 \mathrm{~mm} / \mathrm{h}$ and $6 \mathrm{~min}$ maximum intensity of $28 \mathrm{~mm} / \mathrm{h}$. Two peaks of rainfall can be seen in Figure 3 with instantaneous rainfall intensity reaching $40 \mathrm{~mm} / \mathrm{h}$ and $100 \mathrm{~mm} / \mathrm{h}$, respectively. In addition, the ARI was $22.6 \mathrm{~mm}$ and the surface showed a sedimentary crust. The runoff coefficient was relatively low upstream of the grass strip $(13.3 \%)$ because the winter wheat cover was well developed at this date. Nevertheless, the grass strip efficiency for runoff reduction was very low $(7.3 \%)$. This result is due to the second rainfall peak during which the runoff plus the rainfall rate exceeded the infiltration capacity of the grass strip.

The equivalent grass strip infiltration capacity was calculated, assuming a runoff velocity of $0.15 \mathrm{~m} / \mathrm{s}$ in the winter wheat field and of $0.10 \mathrm{~m} / \mathrm{s}$ in the grass strip. The estimate of the runoff velocity in the field is based on previous field runoff velocity measurements under similar conditions [6]. The runoff velocity within the grass strip could be estimated from the delay between runoff peaks measured on the control plot (no grass strip) and the plot with a 6-m grass strip, which was ca. 1 min on average (for the runoff velocity in the grass strip). The maximum infiltration capacity at a given instant $\mathrm{t}\left(\mathrm{Inf}_{\cdot \max (t)}\right)$ was then calculated by taking the maximum value calculated using the following equation:

Inf. $_{(\mathrm{t})}=\left(\right.$ Int $_{{ }_{\mathrm{t}}}+$ Int $\left._{\cdot \mathrm{t}-1 \mathrm{~min}}\right) / 2+\operatorname{Runoff}_{\mathrm{t}-1 \min (\mathrm{C})}-\operatorname{Runoff}_{\mathrm{t}(\mathrm{GS})}(4)$

with Inf. $(\mathrm{t})=$ the infiltration rate at time $t$, Int. $_{\mathrm{t}}=$ the rainfall intensity at time $t$, Runoff $_{t-1} \min (\mathrm{C})=$ the cumulative Runoff from the control plot at time $\mathrm{t}-1$, the cumulative $\operatorname{Runoff}_{\mathrm{t}(\mathrm{GS})}=$ the runoff from the grass strip plot at time $t$.

The calculated maximum infiltration capacity ranges between 50 and $60 \mathrm{~mm} / \mathrm{h}$.

During the event on December 25, 1997 totalling $3.8 \mathrm{~mm}$ of rainfall and a mean intensity of $1.3 \mathrm{~mm} / \mathrm{h}$, the runoff coefficient on the control plot was, on the contrary, very high $(69.3 \%)$. $84.5 \%$ of the runoff infiltrated on the grass strip, resulting in a runoff coefficient of only $10.7 \%$ for the grass strip plot (Fig. 4). For this event, antecedent rainfall was high (ARI $=12.1 \mathrm{~mm}$ ) and the field was bare and crusted. Peak runoff plus the rainfall 


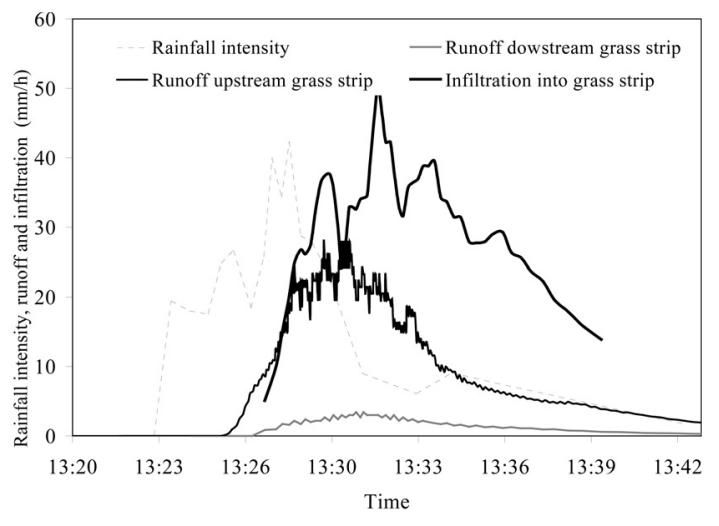

Figure 4. Rainfall intensity, runoff entering and leaving the 6-m grass strip and calculated grass strip infiltration capacity for the event of December 25, 1997.

rate was $56 \mathrm{~mm} / \mathrm{h}$, thus close to the estimated maximum potential infiltration capacity of the grass strip. The maximum runoff rate below the grass strip was only $3.4 \mathrm{~mm} / \mathrm{h}$, which means that runoff used almost the entire surface for re-infiltration.

The same range of values for the maximum infiltration capacity of the grass strip was obtained for other events under wet conditions. However, runoff could be observed below the grass strip for lower upstream runoff and rainfall intensities. This is probably due to the existence of concentrated runoff pathways in the grass strip. Consequently, only a part of the grass strip is used for infiltration of incoming runoff water, especially during low-intensity events $[4,8]$. In addition, local infiltration capacity along preferential runoff pathways across the grass strip may be lower than the global average infiltration capacity, because of the presence of sediment deposits. From our data, it is difficult to say to what extent the variability of infiltration capacity within the strip and/or variations in the strip area effectively used for infiltration contribute to this variability. An estimated $50 \mathrm{~mm} / \mathrm{h}$ maximal infiltration can be used as a reference value for modelling infiltration in grass strips for high rainfall events under wet conditions, but this value overestimates infiltration for minor events during which only part of the grass strip is used for runoff re-infiltration.

\subsection{Effect of grass strip width on runoff}

The above results were obtained by comparing runoff from the control plot without a grass strip with runoff from a plot with a 6-m-wide grass strip. Measurements on the small runoff plots with a 3-m-wide grass strip showed a lower efficiency for runoff reduction compared with the 6-m-wide strip. During the first season of measurement, the overall efficiency of the 3-m grass strip was $60 \%$ against $86 \%$ for the 6-m-wide strip. For the second season, efficiency was $73 \%$ for the 3 -m grass strips against $80 \%$ for the $6-\mathrm{m}$ grass strips. More interesting is the fact that the coefficient of variation of the efficiency between replicates is lower for the 6-m than it is for the 3-m-wide grass strip (27\% vs. $46 \%)$. Thus, although the benefit of a larger grass strip seems to be relatively limited at first glance, it may be more secure in the long term.

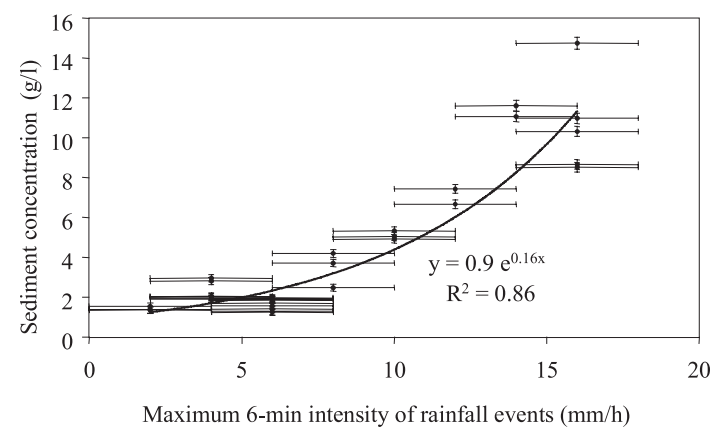

Figure 5. Sediment concentration in runoff entering the 6-m grass strip vs. maximum 6 min rainfall intensity for rainfall events $<5 \mathrm{~mm}$ (bars indicate the measurement error of rainfall intensity: $\pm 2 \mathrm{~mm} / \mathrm{h}$ ).

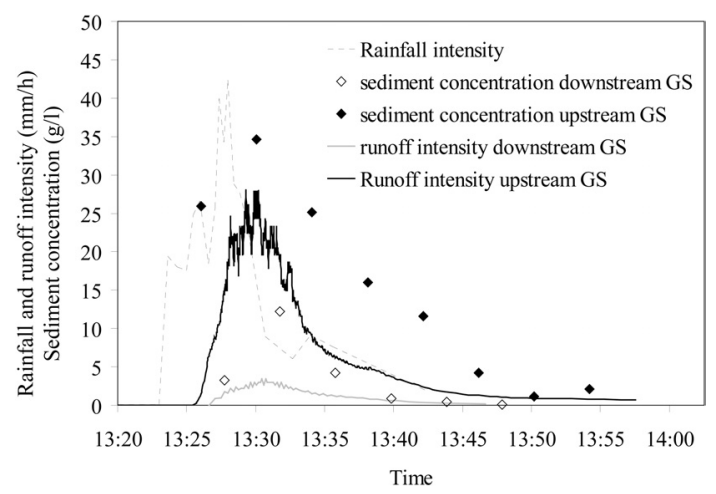

Figure 6. Effect of the 6-m grass strip on runoff and sediment dynamics for the 25 December 97 event.

\subsection{Effect of 6-m grass strips on sediment concentration in runoff}

Mean event sediment concentrations in the runoff from the wheat field ranged from 0.9 to $23.8 \mathrm{~g} / \mathrm{l}$. Overall, there is no correlation between sediment concentration and runoff discharge, although the highest sediment concentrations were observed for the highest runoff discharges. Sediment concentration is generally related to maximum 6-min rainfall intensity, particularly for small rainfall events $<5 \mathrm{~mm}$ (Fig. 5) but not with mean rainfall intensity, which is not a good characterisation of the erosivity of the rain.

The analysis of the sediment concentration variability during a rainfall event shows the effect of rainfall and runoff intensities on the instantaneous sediment concentration (Fig. 6). However, no significant relation exists between rainfall intensity, runoff rate and sediment concentration for the whole observation period. This is mainly due to the effect of vegetation cover. The development of the winter wheat led to a general decrease in sediment concentration (for similar rainfall intensities and runoff rates) between October and late spring when a full vegetation cover became established.

Mean event sediment concentration in the runoff downstream of the grass strip ranged from 0.07 to $5.9 \mathrm{~g} / \mathrm{l}$ during the 
two seasons (6-m grass strip). Mean event sediment concentration was generally reduced to a quarter or less downstream of the grass strip. The effect of the grass strip slightly increased with time during the growing season, probably due to grass development. This result is not in agreement with experiments conducted under rainfall simulation that showed a decrease in the efficiency of grass strips with time [5, 29]. This difference could be due to the relatively short time lapse between the rainfall simulation experiments, leading to higher initial moisture contents and therefore lower infiltration capacities in consecutive experiments.

The event of December 25, 1997 is representative of the variable reduction of the sediment concentration by the grass strip (Fig. 6). Grass strip efficiency for sediment trapping is reduced at high runoff rates $(12.3 \mathrm{~g} / 1$ downstream of the grass strip against $34.6 \mathrm{~g} / \mathrm{l}$ on the control plot for the runoff peak) compared with low runoff rates $(0.5 \mathrm{~g} / \mathrm{l}$ downstream of the grass strip against $11.6 \mathrm{~g} / \mathrm{l}$ on the control plot at the end of the event). Van Dijk et al. [29] proposed a linear relationship between upstream and downstream grass strip sediment concentration (Eq. (5)):

$$
\mathrm{C}_{\text {down }}=\mathrm{a} \cdot \mathrm{C}_{\text {up }} \text { b.L }
$$

with $\mathrm{L}=$ grass strip width, and $\mathrm{a}$ and $\mathrm{b}$ adjusted parameters.

The slope of this relationship is a function of grass strip width. The calculated slope from the optimised parameters given by these authors for a 6-m-wide grass strip with young grass is 0.234 . This parameter can be compared with the slope of the relationship between upstream and downstream grass strip sediment concentration for our data which is 0.236 with $\mathrm{n}=39$ natural rainfall events during two seasons. This experimental value is remarkably similar to the predicted value. However, the coefficient of determination is quite low $\left(\mathrm{R}^{2}=0.39\right)$, indicating that other factors than upstream sediment concentration and grass strip width (such as rainfall characteristics, soil moisture and surface conditions) influence its efficiency for sediment trapping.

\subsection{Selectivity of sediment transport and trapping}

Transported sediment size (apparent grain size distribution) and elementary particle size (elementary grain size distribution after dispersion) were analysed for the samples taken in the first runoff event after pesticide treatment on February 27, 1998 in order to assess the selectivity of erosion and sediment trapping in the grass strip (Tab. II). A sample of the soil surface horizon was also analysed as a reference. All apparent size classes contain clay. Overall, $75 \%$ of the clay fraction is aggregated and transported within coarser particle classes.

The analysis of the sediments collected on the control plot shows that the erosion process is slightly selective, with an enrichment of the $<20 \mu \mathrm{m}$ apparent particles in the sediments compared with the apparent grain size distribution of the surface soil.

Sediment trapping by the grass strip was more selective than erosion, resulting in a doubling of the apparent clay and silt fraction in the sediment leaving the grass strip as compared with the sediments entering the grass strip. This selectivity of sedi-
Table II. Apparent and elementary grain size distribution of the surface horizon and of the sediments entering and leaving the 6-m grass strip for the event of March 4, 1998.

\begin{tabular}{lccccc}
\hline & \multicolumn{5}{c}{ Grain size classes $(\mu \mathrm{m})$} \\
\cline { 2 - 6 } & $0-2$ & $2-10$ & $10-20$ & $20-50$ & $>50$ \\
\hline Apparent grain size distribution $(\%)$ & & & & & \\
Surface horizon & 2.5 & 7.6 & 8.1 & 33.3 & 48.5 \\
Sediments entering grass strip & 4.2 & 9.6 & 8.5 & 30.2 & 47.5 \\
Sediments leaving grass strip & 7.3 & 18.8 & 11.1 & 22.6 & 40.2 \\
Elementary grain size distribution (\%) & & & & & \\
Surface horizon & 9.9 & 9.1 & 6.1 & 37.8 & 37.1 \\
Sediments entering grass strip & 11.3 & 15.0 & 9.8 & 33.5 & 31.4 \\
Sediments leaving grass strip & 22.6 & 16.2 & 9.0 & 24.0 & 28.2 \\
\hline
\end{tabular}

Table III. Cumulative soil loss during the two seasons with no grass strip and with the 3-m and 6-m grass strips.

\begin{tabular}{lccc}
\hline Season & \multicolumn{3}{c}{$\begin{array}{c}\text { Cumulative soil loss } \\
(\mathrm{kg} / \mathrm{ha})\end{array}$} \\
\cline { 2 - 4 } & No grass strip & 3-m grass strip & 6-m grass strip \\
\hline $96 / 97$ & 290 & No data & 70 \\
$97 / 98$ & 882 & 169 & 18 \\
\hline
\end{tabular}

ment transport due to the presence of a grass strip results in an enrichment in elementary clay and fine silt. Conversely, sediment trapped in the grass strip contains more coarse silt and sand.

\subsection{Erosion budget}

The combination of runoff infiltration and sediment trapping leads to a large reduction of sediment export downstream of the grass strip. Soil loss from the field was reduced by $76 \%$ and $98 \%$ downstream of the 6-m grass strip for the two observation seasons (Tab. III). Efficiency was higher during the second season because of a better grass growth and a lower upstream runoff production. The 3-m grass strip reduced soil loss by $81 \%$. Soil loss was limited to $70 \mathrm{~kg} / \mathrm{ha}$ and $18 \mathrm{~kg} / \mathrm{ha}$ downstream of the 6-m grass strip, whereas it reached 290 and $880 \mathrm{~kg} / \mathrm{ha}$ when no grass strip was sown for the two observation seasons. The level of reduction observed is very close to that obtained under rainfall simulation with higher rainfall intensities but smaller rainfall amounts [5].

\section{CONCLUSIONS}

The results from these experiments showed that, in the field situation that was tested, the grass strips were very efficient in reducing runoff as well as sediment concentration for most rainfall events. 
A detailed analysis of runoff and sediment concentration measurements for each rainfall event allowed the explanation of the mechanisms causing this reduction. First of all, the 6-mwide grass strip allowed runoff infiltration with an average efficiency of $80 \%$, ranging from $56 \%$ to $100 \%$ depending on event characteristics. The maximum infiltration capacity of the grass strip was estimated as ca. $50 \mathrm{~mm} / \mathrm{h}$. This potential infiltration capacity is only reached when the grass strip is completely covered by runoff water. When runoff is concentrated in streamlines the actual effective infiltration capacity, and therefore the efficiency of the grass strip, is much lower. Secondly, grass strips trap sediments, reducing sediment concentrations by a factor of four on average. Trapping efficiency decreases with increasing runoff. Our results on trapping efficiency are in very good agreement with the relationship proposed by Van Dijk et al. [29] who carried out experiments with simulated runoff.

The analysis of a limited number of sediment samples suggests that sediment trapping is selective: sediments deposited within the grass strip contain more sand and coarse silt, whereas exported sediments contain twice as much clay and fine silt than the soil surface horizon. Finally, soil loss was reduced by $76 \%$ and $98 \%$ for the $96 / 97$ and $97 / 98$ seasons, respectively, with the 6-m-wide grass strip.

This work allowed the assessment of the effect of grass strips on runoff and sediment losses from arable land under natural rainfall and runoff conditions, and several mechanisms explaining the temporal variability of grass strip efficiency were identified. Further investigations are needed to study the durability of the grass strip efficiency after successive seasons and successive runoff and erosion events, that would lead to a high amount of sediment trapping.

Acknowledgements: The authors are grateful to Bernard Renaux for technical assistance and to the two anonymous reviewers for English language correction. This article was made possible partly due to the support of the BRGM Research Programme (00RISKD02), PNRH national programme (RIDES project) and MATE Gessol programme ("Maitrise de l'érosion" project).

\section{REFERENCES}

[1] Auzet A.-V., Boiffin J., Ludwig B., Concentrated flow erosion in cultivated catchment: influence of soil surface state, Earth Surf. Process and Landforms 20 (1995) 759-767.

[2] Arora K., Mickelson S.K., Baker J.L., Tierney D.P., Evaluating herbicide removal by buffer strips under natural rainfall, The 1993 International Winter Meeting of the A.S.A.E., Chicago, Illinois, USA, paper No. 93-2593, 1993, pp. 12-14.

[3] Asmussen L.E., White A.W., Hauser E.W., Sheridan J.M., Reduction of 2,4-D Load in Surface Runoff Down a Grassed Waterway, J. Environ. Qual. 6 (1977) 159-162.

[4] Barfield B.J., Tollner E.W., Hayes J.C., Filtration of sediment by simulated vegetation. I. Steady-state flow with homogeneous sediment, Trans. ASAE 22 (1979) 540-545.

[5] Barone V.A., Gehring M.E., Christopher K.I., Kirkpatrick A.P., Coffey M.E., Vincent A.A., Buck S.P., Mostaghimi S., Dillaha T.A., Wolfe M.L., Vaughan G.H., Effectiveness of vegetative filter strips in reducing NPS polluant losses from agricultural lands: sediment, nutrients, bacteria, and pesticides, The 1998 Annual Inter- national Meeting of the A.S.A.E., paper No. 98-2037, 1998, pp. $1-$ 17.

[6] Chaplot V., Le Bissonnais Y., Field measurements of interrill erosion under different slopes and plot sizes, Earth Surf. Processes and Landforms 25 (2000) 145-153.

[7] Commission of the European Communities, Towards a Thematic Strategy for Soil Protection. Communication from the Commission to the Council, the European Parliament, The Economic and Social Committee and the Committee of the Regions, EU, Brussels, April 16, 2002, COM (2002) 179 final.

[8] Dillaha T.A., Sherrard J.H., Lee D., Long-term effectiveness and maintenance of vegetative filter strips (1986) VPI-VWRRC-Bull. 153, Virginia Polytechnic Institute and State University, Blacksburg.

[9] Dillaha T.A., Sherrard J.H., Lee D., Mostaghimi S., Shanholtz V.O., Evaluation of vegetative filter strips as a best management practice for feed lots, J. Water Pollut. Control 60 (1988) 1231-1238.

[10] Emama L.E., Morgan R.P.C., Contour grass strips: a laboratory simulation of their role in erosion control, Soil Technol. 8 (1995) 109-117.

[11] Fox D., Le Bissonnais Y., A process-based analysis of the influence of aggregate stability on surface crusting, infiltration, and interrill erosion, Soil Sci. Soc. Am. J. 62 (1998) 717-724.

[12] Gallien E., Le Bissonnais Y., Eimberck M., Benkhadra H., Ligneau L., Ouvry J.F., Martin P., Influence des couverts végétaux de jachère sur le ruissellement et l'érosion diffuse en sol cultivé, Cah. Agric. 4 (1995) 171-183.

[13] Lakew Desta Tadesse, Morgan R.P.C., Contour grass strips: a laboratory simulation of their role in erosion control using live grasses, Soil Technol. 9 (1996) 83-89.

[14] Le Bissonnais Y., Benkhadra H., Chaplot V., Fox D., King D., Daroussin J., Crusting, runoff and sheet erosion on silty loamy soils at various scales and upscaling from $\mathrm{m}^{2}$ to small catchments, Soil Tillage Res. 46 (1998) 69-80.

[15] Le Bissonnais Y., Cerdan O., Lecomte V., Benkhadra H., Souchère V., Martin P., Spatial and temporal variability of soil surface characteristics influencing infiltration, runoff and interrill erosion of cultivated fields, Catena (2004) in press.

[16] Magette W.L., Brinsfield R.B., Palmer R.E., Wood J.D., Nutrient and sediment removal by vegetated filter strips, Trans. ASAE 32 (1989) 663-667.

[17] Miller B.I., Brown L.C., Tollner E.W., Hayes J.C., Franti T.G., Tim U.S., Critical review of data from research on vegetative control systems, ASAE Annual International Meeting, Minneapolis, Minnesota, USA, 10-14 August, 1997, American Society of Agricultural Engineers (ASAE), St Joseph, USA, 1997, No. 972058,13 p.

[18] Misra A.K., Baker J.L., Mickelson S.K., Shang H., Effectiveness of vegetative buffer strips in reducing herbicide transport with surface runoff under simulated rainfall, The 1994 International Summer Meeting of ASAE, Kansas City, Missouri, USA, paper No. 922146, 1994, pp. 1-21.

[19] Munoz-Carpena R., Parsons J.E., Gilliam J.W., Modeling hydrology and sediment transport in vegetative filter strips. J. Hydrol. 214 (1999) 111-129.

[20] Murphy G.P., Shaw D.R., Effect of vegetative filter strip width on reducing fluometuron and norflurazon losses in surface runoff, Tech. Bull. - Mississipi Agric. For. Exp. Station 214 (1997) 1-7.

[21] Neibling W.H., Alberts E.E., Composition and yield of soil particles transported through sod strips, ASAE paper No. 79-2065, 1979, ASAE, St Joseph, Mi. 
[22] Parsons J.E., Daniels R.B., Gilliam J.W., Dillaha T.A., The effect of vegetation filter strips on sediment and nutrient removal from agricultural runoff, Environ. Sound Agric. Conf. (1991) 324-332.

[23] Patty L., Limitation du transfert par ruissellement vers les eaux superficielles de deux herbicides (isoproturon et diflunicanil), Méthodologie analytique et étude de l'efficacité de bandes enherbées, Thèse de l'Université Joseph Fourier, Grenoble I (1997), p. 217.

[24] Robinson J.S., Sivapalan M., Instantaneous response functions of overland flow and subsurface stormflow for catchment models, Hydrol. Process. 10 (1996) 845-862.

[25] Rohde W.A., Asmussen L.E., Hauser E.W., Wauchope R.D., Allison H.D., Trifluralin movement in runoff from a small agricultural watershed, J. Environ. Qual. 9 (1980) 37-42.
[26] Souchère V., King C., Dubreuil N., Lecomte V., Le Bissonnais Y., Chalat M., Grassland decrease: role of socio-economic factors and consequences for runoff and soil erosion, Environ. Sci. and Policy 6 (2003) 7-16.

[27] Spatz R., Walker F., Hurle K., Effect of grass buffer strips on pesticide runoff under simulated rainfall, Med. Fac. Landbouww Univ. Gent 62 (1997) 799-806.

[28] Tingle C.H., Shaw D.R., Boyette M., Murphy G.P., Metolachlor and metribuzin losses in runoff as affected by width of vegetative filter strips, Weed Sci. 46 (1998) 175-479.

[29] Van Dijk P.M., Kwaad F.J.P., Klapwijk M., Retention of water and sediment by grass strips, Hydrol. Process. 10 (1996) 1069-1080.

[30] Young R.A., Huntrods T., Anderson W., Effectiveness of Vegetated Buffer Strips in controlling Pollution from Feedlot Runoff, J. Environ. Qual. 9 (1980) 483-487. 